\title{
Investigation on Strength and Workability at Low Temperature by Using Locally Available Materials
}

\section{Shaief Manzoor*}

Baba Ghulam Shah Badshah University, Rajouri, Jammu and Kashmir, India

\begin{abstract}
Kashmir lies in region where temperature in winter is very low. The temperature in Kashmir is often below $0^{\circ} \mathrm{C}$ during couple of months winter. Concrete mixed, transported and placed under low temperatures requires an understanding for the adverse effects of such environmental factors on the durability of concrete. The damage caused by extreme weather conditions can never be fully eliminated but efforts can be made to minimize these adverse effects. This research was undertaken to investigate the effects of Extreme weather on different properties of concrete and influence of early temperature on the strength of concrete.
\end{abstract}

Three temperatures, two $5^{\circ} \mathrm{C}$ and one $25^{\circ} \mathrm{C}$ were selected and maintained for the first three days for freshly prepared concrete and during the early hardening state of concrete. After three days all the samples were cured at room temperature. The most common traditional mix of 1:2:4 was selected for the research work because it is used for maximum construction projects. Admixtures Sodium Nitrite was used to see useful effects of these during extreme weather conditions.

After the conduct of research, it has been concluded that cold wheather concreting has serious effect on different properties of concrete, like strength, workability and rate of hardening, during the early hardening state. To eliminate the ill effects, it is the duty of the designer/engineer to plan in advance the selection of materials, types quality and quantity of admixtures and coordination of all phases of work so that conreting can be done safely without damage from freezing throughout the winter months in cold climates.

\section{Keywords: Investigation; Concrete; Climates}

\section{Introduction}

The normal procedure adopted for concreting in fair weather will not be valid for concreting when the temperature is low or below the freezing point. The production of concrete in cold weather introduces special and peculiar problems, such as delay in setting and hardening, damage to concrete in plastic condition when exposed to below freezing point owing to the formation of ice lenses Therefore, it is essential to maintain the temperature of the concrete positively above $0^{\circ} \mathrm{C}$, possibly at much higher temperature. Any concreting operation done at a temperature below $5^{\circ} \mathrm{C}$ is termed as cold weather concreting

There are two main problems with concrete in cold weather:

i. Concrete can freeze before it gains strength which breaks up the matrix

ii. Concrete sets more slowly when it is cold very slow below $50^{\circ} \mathrm{F}$; below $40^{\circ} \mathrm{F}$ the hydration reaction basically stops and the concrete doesn't gain strength.

iii. Hardened concrete subjected to alternate Freezing and Thawing.

\section{Effects of cold weather on concrete}

Cold weather affects the concrete in following manner:

1. Delay in setting and hardening period because rate of hydration.

2. Delay in setting time makes concrete vulnerable to frost attack and other disturbances.

3. Progress of work is slowed down and removal of formwork is delayed thus affecting economically.
4. Loss of compressive strength even upto $50 \%$ incase, if concrete freezes when it is in plastic state.

5. Durability of the concrete is impaired due to freezing and thawing of fresh or hardened concrete.

6. Large temperature differentials within the concrete member may promote cracking while removal of formwork in cold weather (Figures 1-3).

\section{Purpose and Scope of Present Research}

The main aim of the research was to study

- The cold weather effects on concreting during the early time of setting and gaining strength.

- Influence of first three days temperature on 28-days compressive strength of concrete was studied and analyzed.

- Also effect of low temperature on the workability of concrete was investigated.

- Low temperature effects on Tensile strength and modulus of rupture were also considered.

*Corresponding author: Shaief Manzoor, Baba Ghulam Shah Badshah University, Rajouri, Jammu and Kashmir, 185131, India, Tel: +919419023302, +91700634373; E-mail: shaief38@gmail.com

Received June 12, 2017; Accepted June 30, 2017; Published July 06, 2017

Citation: Manzoor S (2017) Investigation on Strength and Workability at Low Temperature by Using Locally Available Materials. J Steel Struct Constr 3: 131. doi: 10.4172/2472-0437.1000131

Copyright: (C) 2017 Manzoor S. This is an open-access article distributed under the terms of the Creative Commons Attribution License, which permits unrestricted use, distribution, and reproduction in any medium, provided the original author and source are credited. 


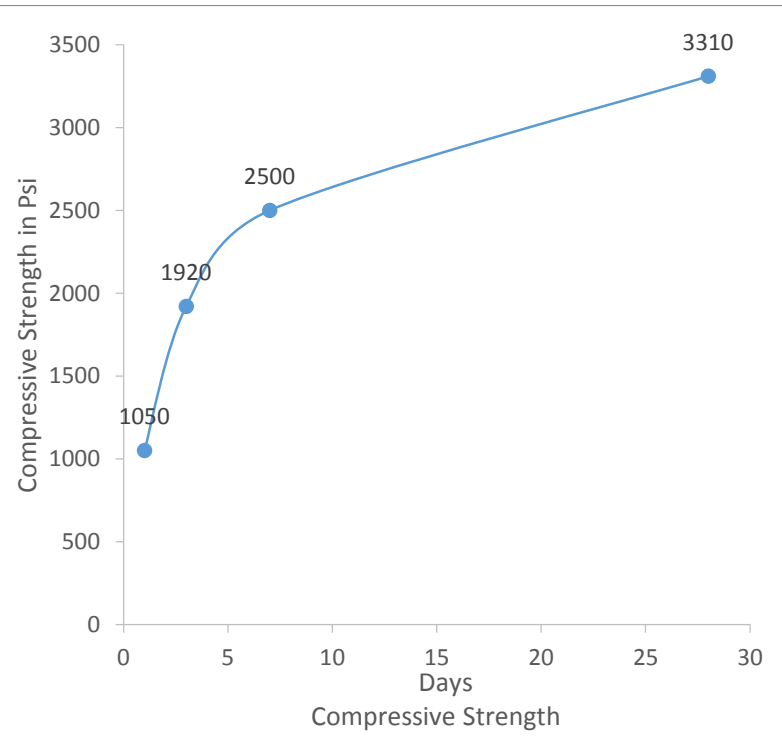

Figure 1: Graph Showing Compressive with variation in room temperature.

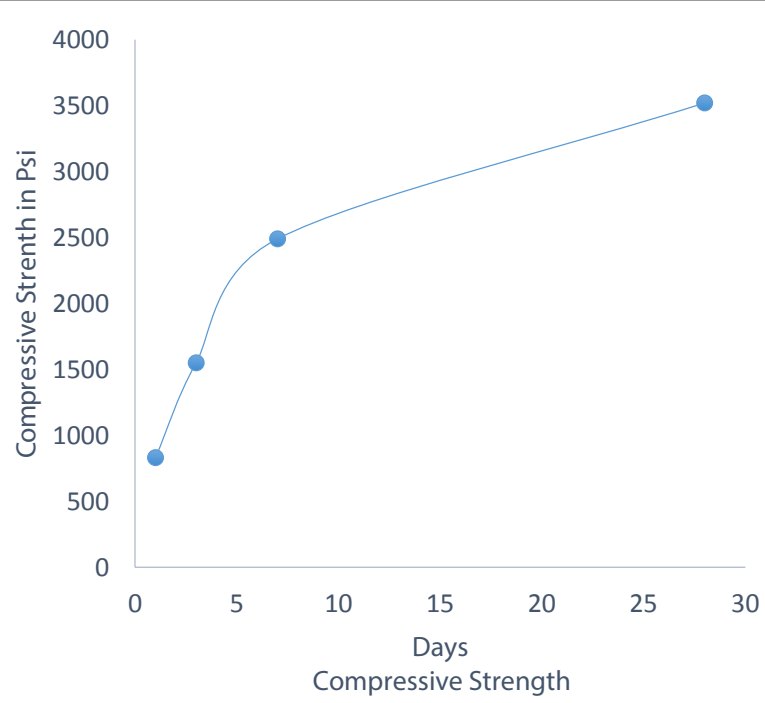

Figure 2: Graph Showing Compressive with variation in temperature $\left(5^{\circ} \mathrm{C}\right)$

- An admixture Sodium Nitrite was added to study the effects an admixture on strength of concrete during a cold weather.

\section{Methodology and Materials Used}

Locally available materials were used in this research work. Details are as following:

\section{Cement: Ambuja Cement}

Aggregates: Sand (Obtained from River Jehlum near Anantnag)

Coarse Aggregates: Locally available crush

\section{Admixtures: Sodium Nitrite}

Testing of constituent materials was carried out as per ASTM specified procedures.

Although one concrete mix was taken i.e., 1: 2:4 with w/c ratio 0.65 but the temperature was varied. It was varied according to possible

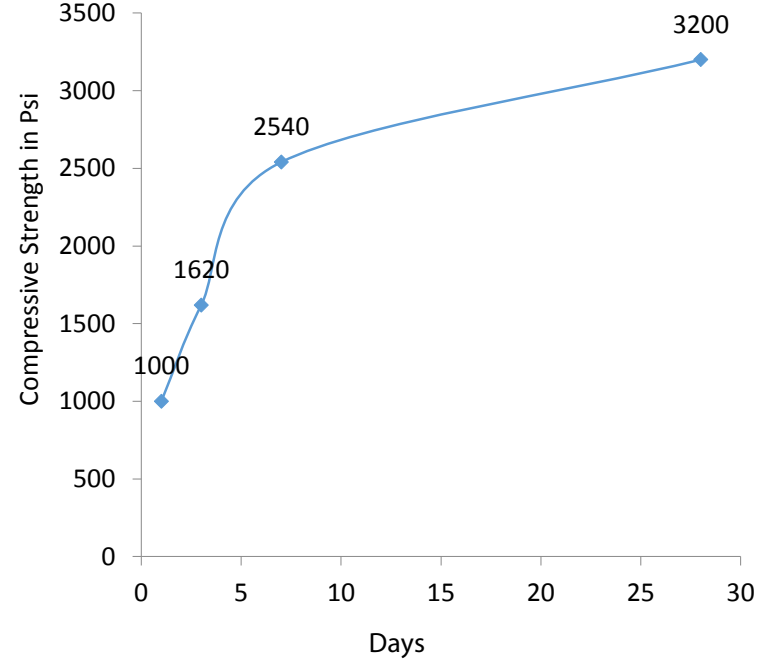

Figure 3: Graph Showing Compressive with variation in temperature $\left(5^{\circ} \mathrm{C}\right)$ with admixture.

extreme weather temperature, which a concrete mix can come across during first three days. Temperatures selected were $5^{\circ} \mathrm{C}$, and $25^{\circ} \mathrm{C} .1,3$, 7 and 28-day tests were carried on samples prepared.

A manually operated drum mixer, having a maximum of $2.5 \mathrm{cft}$ capacity was used for mixing concrete

\section{Results and Conclusions}

\section{Effect on compressive strength}

The specimens manufactured at low temperature $\left(5^{\circ} \mathrm{C}\right)$ showed slow gain of one-day compressive strengths as compared to those made at room temperatures. Those samples put on low temperature started recovering by the seventh day and there strength was almost equal to room temperature samples. At 28th day compressive strength of the cylinders placed at low temperature gained slow early days strength but later recovered and seem to have more strength than normal room temperature made cylinders. Use of admixtures low temperatures seem to be beneficial to some extent. The admixture Sodium Nitrite has shown some early gain of strength but 28 days strength was reduced (Tables 1 and 2; Figures 4 and 5).

\section{Effect on workability}

With constant w/c ratio and variable temperature it was found that workability of concrete mix decreases as the temperature of the concrete increases i.e., slump and the compacting factor values decreases as the temperature increases. But when the surrounding and concrete temperature is low there is no such effect on the workability. The use of Sodium Nitrite has no notable effect on the workability of concrete at low temperature.

\section{Effect on modulus of rupture}

It is seen by test results that prisms/beams made at room temperature showed less tensile strength at 28th days as compared to samples made are $5^{\circ} \mathrm{C}$. While the samples in which admixture was used showed higher modulus of rupture as compared to the samples, which were without admixture. Thus values of modulus of rupture of concrete are greatly affected by the variation in temperature. 
Citation: Manzoor S (2017) Investigation on Strength and Workability at Low Temperature by Using Locally Available Materials. J Steel Struct Constr 3: 131. doi: 10.4172/2472-0437.1000131

Page 3 of 4

\begin{tabular}{|c|c|c|c|c|c|c|c|}
\hline \multirow[t]{2}{*}{ S. No. } & \multirow[t]{2}{*}{ Condition } & \multirow{2}{*}{$\begin{array}{c}\text { Temperature }{ }^{\circ} \mathrm{C} \\
\text { (First } 3 \text { days) }\end{array}$} & \multirow[b]{2}{*}{ 1-Day } & \multicolumn{4}{|c|}{ Compressive Strength (Psi) } \\
\hline & & & & 3-Day & 7-Day & 28-Day & Remarks \\
\hline 1 & Room Temperature & $25^{\circ} \mathrm{C}$ & 1050 & 1920 & 2500 & 3310 & \\
\hline 2 & Low Temperature & $5^{\circ} \mathrm{C}$ & 830 & 1550 & 2490 & 3250 & $2 \%$ decrease in 28 days strength \\
\hline 3 & Low Temperature with admixture & $5^{\circ} \mathrm{C}$ & 1000 & 1620 & 2540 & 3200 & $3.3 \%$ decrease in 28 days strength \\
\hline
\end{tabular}

Strength of cylinders at various ages

Mix ratio: $1: 2: 4$, w/c ratio- 0.65

Table 1: Test Results for Compressive.

\begin{tabular}{|c|c|c|c|}
\hline S. No. & Condition & Temperature ${ }^{\circ} \mathrm{C}$ & Slump (MM) \\
\hline 1 & Room Temperature & $25^{\circ} \mathrm{C}$ & 58 \\
\hline 2 & Low Temperature & $5^{\circ} \mathrm{C}$ & 56 \\
\hline 3 & Low Temperature with admixture & $5^{\circ} \mathrm{C}$ & 0.87 \\
\hline
\end{tabular}

Measurement of slump and Compaction factor

Mix ratio: $1: 2: 4, w / c$ ratio- 0.65

Table 2: Test results for workability.

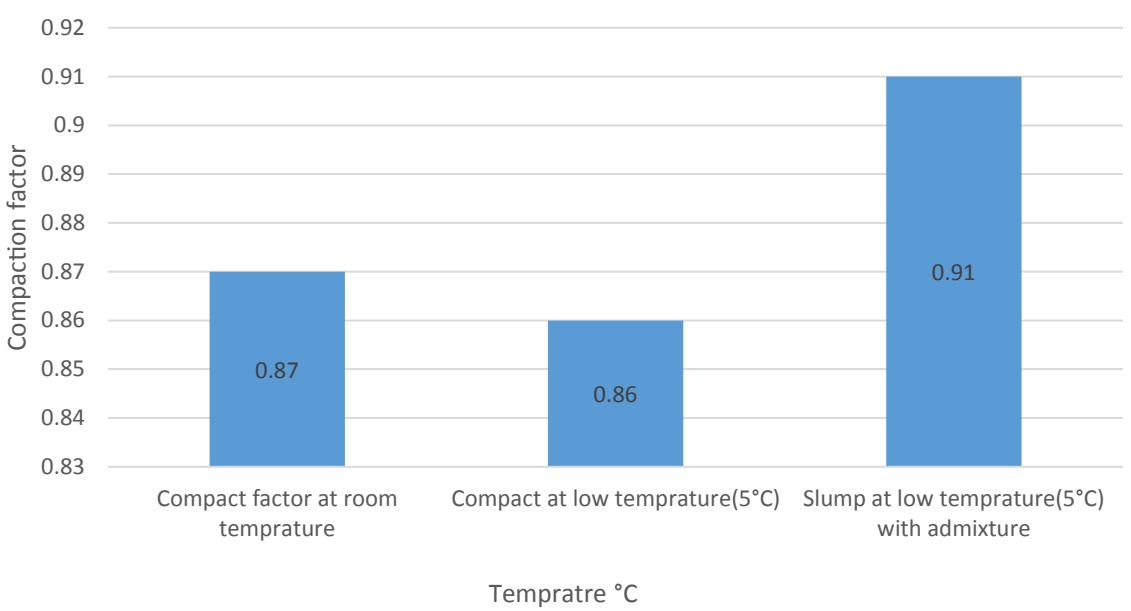

Figure 4: Temperature Effect on compaction factor.

Temprature Effect onSlump

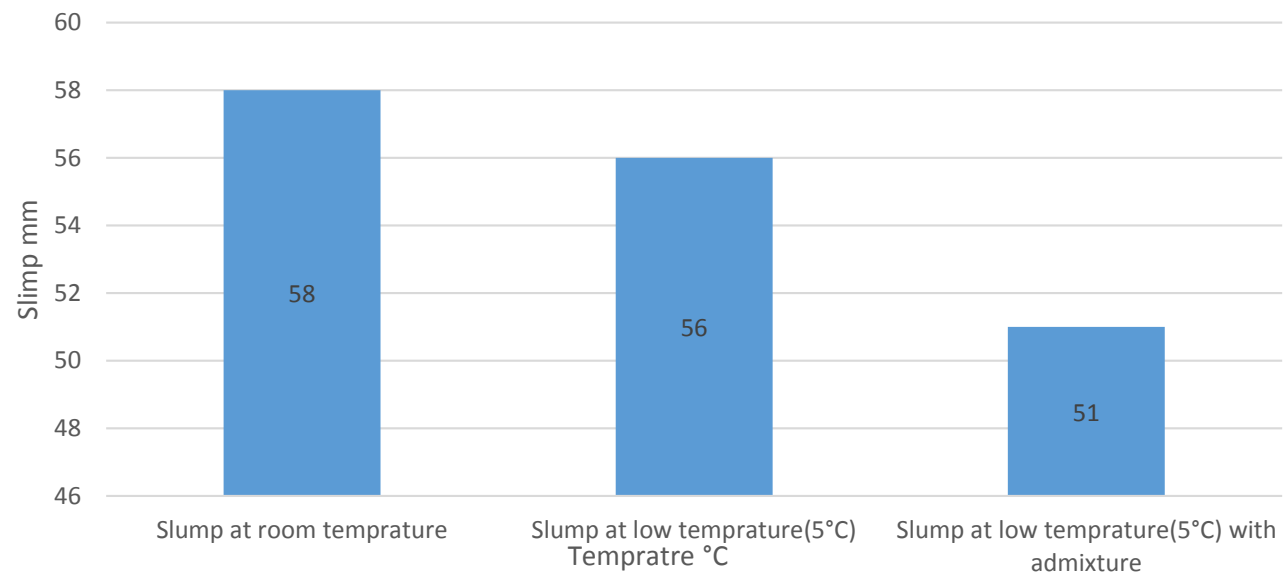

Figure 5: Temperature Effect on slump. 


\section{Effect on tensile strength}

Splitting tensile strength test was performed to evaluate the effect of temperature on tensile strength of concrete. It was observed that as the temperature increases, there is quick early gain of tensile strength but later 28-day tensile strength was decreased, as in the case of compressive strength.

\section{Recommendations}

- If the temperature is too low it should be given importance by site engineer while concreting.

- Plan all concreting works completed during suitable weather/ temperature so that newly placed concrete should not encounter odd temperature.
- High temperature showed early gain of strength but later the strength of concrete was considerably reduced.

- Temperature of ingredients of concrete should be given consideration to control the temperature of the concrete.

- Cold weather may cause delay in setting and hardening period, thus delaying removal of formwork.

- Use chemical means (admixtures) to prevent damage/loss of strength. It is not that much expensive as compared to loss that can occur to concrete without chemicals by extreme temperature.

- Certain precautionary measures are highly recommended for concreting both in hot and cold weathers. 